\title{
Donor Granulocyte Transfusions in Febrile Neutropenic Pediatric Oncology Patients
}

\author{
Gulay SEZGIN ${ }^{1}$, Can ACIPAYAM ${ }^{1}$, Ferda T. TURHAN ${ }^{2}$, Ayse OZKAN $^{1}$, Serhan KUPELI' \\ Ibrahim BAYRAM' ${ }^{1}$, Birol GUVENC ${ }^{3}$, Atila TANYELI ${ }^{1}$ \\ ${ }^{1}$ Çukurova University Faculty of Medicine, Department of Pediatric Oncology and Bone Marrow Transplan Unit \\ ${ }^{2}$ Çukurova University Faculty of Medicine, Department of Hemapheresis Unit \\ ${ }^{3}$ Çukurova University Faculty of Medicine, Department of Hematology, Adana, TURKEY
}

\begin{abstract}
To describe the clinical course of febrile neutropenic pediatric oncology patients undergoing granulocyte transfusions (GTF), we performed a retrospective chart review of all pediatric oncology patients with febrile neutropenia receiving granulocyte transfusions between September 2009 and September 2011 in a University Hospital setting. Thirty-seven patients received a total of 51 courses of GTFs. In 35 febrile episodes patients had leukemia and in 16 episodes patients had solid tumors. Three patients received allogeneic hematopoietic stem cell transplantation from their HLA identical sibling. Mean duration of fever and neutropenia was $18.5 \pm 17.5$ days. Infections were classified as fever of unknown origin $(21 \%, n=11)$, microbiologically documented infection $(44 \%, n=23)$, clinically suspected infection $(35 \%$, $n=$ 18). The mean granulocyte yield, WBC count and granulocyte count of the products were $3.1 \pm 1.2 \times 10^{10} / \mathrm{unit}^{1}, 158.6 \pm 66.4 \times 10^{3} / \mathrm{mm}^{3}$ and $134.5 \pm 62 \times 10^{3} / \mathrm{mm}^{3}$, respectively. The median donor WBC count at leukapheresis was $32.91 \times 10^{9} / \mathrm{L}$. GTFs were well tolerated except one patient who had fever during transfusion. Thirty-nine (76.5\%) of the episodes resolved from infection and discharged from the hospital. Of the 12 patients (23.5\%) who died, seven of them were refractory to treatment, three patients had relapsed disease and two patients had newly diagnosed disease. This case series documents the course of 37 septic neutropenic pediatric oncology patients who underwent a total of 51 GTF courses. GTFs were generally well tolerated and improve short-term outcome in neutropenic pediatric oncology patients.
\end{abstract}

Keywords: Donor granulocyte transfusion, Febrile neutropenia, Childhood

ÖZET

Febril Nötropenik Pediatrik Onkoloji Hastalarında Donör Granülosit Transfüzyonları

Bu çalışmada febril nötropeni gelişen kanserli çocuk hastaların granülosit transfüzyonu sonrası klinik durumlarının izlenmesi amaçlandı. Eylül 2009 ile Eylül 2011 yılları arasında üniversite hastanesinde, nötropenik ateş nedeniyle granülosit tranfüzyonu verilen hastaların retrospektif olarak dosyaları incelenmiştir. Otuz yedi hasta toplam ellibir granülosit transfüzyonu almıştır. Febril atakların 35 'inde lösemi, 16 atakta ise solid tümör tanısı mevcut idi. Üç hastaya HLA uygun kardeşten allojeneik kök hücre nakli yapılmış idi. Ortalama ateş ve nötropeni süresi $18.5 \pm 17.5$ gün saptandı. Hastaların \%21'inde $(n=11)$ sebebi bilinmeyen ateş, \%44'ünde $(n=23)$ mikrobiyolojik olarak kanıtlanmış enfeksi-

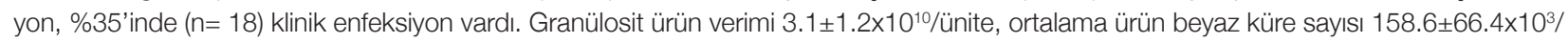
$\mathrm{mm}^{3}$ ve ortalama ürün granülosit sayısı $134.5 \pm 62 \times 10^{3} / \mathrm{mm}^{3}$ bulundu. Lökaferezde vericinin ortanca beyaz küre sayıSI $32.91 \times 10^{9} / \mathrm{L}$ olarak saptandı. Granülosit transfüzyonları bir hastada transfüzyon sırasında gelişen ateş dışında iyi tolere edilmişti. Otuz dokuz atakta (\%76.5) hastalar iyileşerek taburcu edilmiş; 12 (\%23.5) atak sonrasında hasta kaybedilmiştir. Kaybedilen hastaların yedisinde refrakter hastalık, iki tanesi yeni tanı ve üçünde de relaps hastalık saptanmıştı. Bu makalede 51 granülosit transfüzyonu alan septik nötropenik 37 pediatrik onkoloji hastasının kliniği incelenmiştir. Granülosit transfüzyonlarının iyi tolere edildiği ve kısa dönemde sağkalımı iyi yönde etkilediği görülmüştür.

Anahtar kelimeler: Donör granülosit transfüzyonu, Febril nötropeni, Çocukluk çağı 


\section{INTRODUCTION}

An increasing number of clinical disorders are being treated with chemotherapy and hematopoietic stem cell transplantation. Neutropenia is the most frequent side effect of these aggressive treatments and in spite of modern antimicrobials and supportive therapy, infections are still cause of mortality and morbidity in these patients. ${ }^{1}$ Although it is a logical approach to give granulocyte transfusions (GTFs) to neutropenic patients just as RBC transfusion to anemic patients or platelet transfusion to thrombocytopenic patients, it is still an underutilized mode of therapy. The use of GTF in neutropenic patients began in the early 1970s. Due to the adverse effects such as severe pulmonary reactions, conflicting results on the efficacy and questions about the appropriate dosing of GTFs has led abandoning its use as a therapeutic modality. The development of better apheresis techniques and the use of G-CSF (granulocyte colony stimulating factor) brought GTFs back to attention in the 2000s. Several trials have shown the effect of granulocyte transfusion in neutropenic pediatric patients with severe infections. Following GTF, fungal and bacterial infections were very well controlled and mortality had been shown to decrease. ${ }^{2-4}$

In this study, the effect of donor granulocyte transfusions on clinical course of pediatric oncology patients with febrile neutropenia was investigated.

\section{PATIENTS AND METHODS}

\section{Patients}

We performed a retrospective chart review of 37 pediatric cancer patients with febrile neutropenia who received GTFs between September 2009-September 2011. Patients who received GTFs had absolute neutrophil count less than $500 / \mathrm{mm}^{3}$, neutropenia longer than 7 days or presented with clinical signs of uncontrolled infection eg. respiratory failure or hypotension or neutropenia from HSCT.

\section{Donors}

Granulocytes were collected from related or unrelated healthy volunteers. Volunteers were selected after screening their suitability for blood donation on the basis of ABO-Rhesus and cross match compatibility, negative serology for HAV, HBV, HCV, HIV and CMV, VDRL and normal values in blood tests. Informed consent was obtained from all donors. Donors were stimulated with recombinant human G-CSF 5 micrograms $/ \mathrm{kg}$ of bodyweight and/or $8 \mathrm{mg}$ oral dexamethasone 12 hours before collection as granulocyte mobilization protocol.

\section{Leukopheresis}

A total of 51 granulocyte apheresis sessions were performed on 37 healthy volunteers at the Hemapheresis Unit of Balcali Hospital. All procedures were carried out using a $\mathrm{COBE}^{\circledR}$ Spectra (Terumo BCT, Inc. Lakewood, CO, USA) apheresis device. An average of $5249 \mathrm{ml}$ of donor blood was processed with a mean duration of 101 minutes. To achieve both adequate anticoagulation and a better separation of granulocytes, $30 \mathrm{ml}$ of $46.7 \%$ trisodium citrate solution was added to a $500 \mathrm{ml}$ bag of $6 \%$ hydroxyethyl starch (Voluven, Fresenius Kabi, Bad Homburg, Germany). An average of $414 \mathrm{ml}$ of this citrate-containing solution was used continuously at a 1:13 ratio with whole blood during the procedures. Vascular access was provided by peripheral veins in all cases. Intravenous calcium supplementation was required in six sessions. The mean granulocyte concentrate yield was $3.1 \pm 1.2 \times 10^{10} /$ unit (range, $0.7 \times 10^{10}$ and $8.8 \times 10^{10}$ ), and the average product volume was $246.3 \mathrm{ml}$. Granulocyte concentrates were irradiated with a minimum dose of 25 Gy of gamma-radiation before transfusion, and the mean storage time of the products was 2.4 hours (range, 30 min-5.5 hours). All donors were monitored carefully throughout the procedures by an apheresis nurse. Vital signs were measured and recorded every 30 minutes. All procedural data and adverse events were also recorded on a dedicated sheet.

\section{GTF}

The granulocytes were transfused the same day usually 3-6h after apheresis. Preventive measures taken before GTFs consisted of a premedication with pheniramine maleate $(1 \mathrm{mg} / \mathrm{kg}$ intravenous) and methylprednisolone (1-2 mg/kg intravenous). Transfusionrelated complications such as fever, chills, pulmonary adverse reactions (cough, dyspnea, hypoxia, changes on the chest radiograph), transfusion associated graft versus host disease and hemolytic reactions were recorded. Monitoring during GTF included continuos registration of oxygen saturation and measurement of blood pressure, respiratory rate and heart rate every $15 \mathrm{~min}$. GTFs were transfused over 1-4h. To reduce possible side effects, amphotericin was not administered 4 hours before and after GTF. 
International Journal of Hematology and Oncology

Table 1. Characteristics of the patients/episodes

\begin{tabular}{|c|c|}
\hline & Number (\%) \\
\hline Number of episodes & 51 \\
\hline \multicolumn{2}{|l|}{ Age (months) } \\
\hline Median & 89 \\
\hline Range & $5-231$ \\
\hline Sex (male/female) & $25 / 12(68 / 32)$ \\
\hline \multicolumn{2}{|l|}{ Underlying malignancy } \\
\hline Solid tumor & $16(31)$ \\
\hline Neuroblastoma & 5 \\
\hline Ependymoma & 3 \\
\hline Medulloblastoma & 2 \\
\hline $\mathrm{NHL}$ & 2 \\
\hline Wilms' tumor & 1 \\
\hline Rhabdomyosarcoma & 1 \\
\hline Osteosarcoma & 1 \\
\hline Ewing sarcoma & 1 \\
\hline Acute leukemia & $35(69)$ \\
\hline ALL & 20 \\
\hline AML & 15 \\
\hline \multicolumn{2}{|l|}{ Status of cancer } \\
\hline Remission & 39 (76.5) \\
\hline Nonremission & $12(23.5)$ \\
\hline Remission induction & 2 \\
\hline Relapse/refractory & 10 \\
\hline \multicolumn{2}{|l|}{ Entry ANCseverity } \\
\hline$\leq 100 / \mathrm{mm} 3$ & $22(43)$ \\
\hline$>100 / \mathrm{mm} 3$ & $29(57)$ \\
\hline Mean duration of FEN (days \pm SD) & $18.5 \pm 17.5$ \\
\hline Central venous cathether & $16(31)$ \\
\hline Patients receiving G-CSF & $31(61)$ \\
\hline Patients receiving IVIG & $15(30)$ \\
\hline \multicolumn{2}{|l|}{ Procalcitonin ( $\mu \mathrm{g} / \mathrm{L})$} \\
\hline$\leq 0.5$ & $23(45)$ \\
\hline$>0.5$ & $28(55)$ \\
\hline Mucositis & 29 \\
\hline Steven-Johnson syndrome & 3 \\
\hline
\end{tabular}

\section{Statistical Analysis}

Statistical data analysis was performed using SPSS package. The data were summarized in a descriptive analysis. Cumulative survival was evaluated by Kaplan-Meier method. To compare survival rates, log-rank test was performed. Mann-Whitney U tests, Nonparametric test (Spearman's rho test) were used for comparison of groups of continuous variables. P value $<0.05$ was considered statistically significant.

\section{RESULTS}

\section{Clinical characteristics}

From September 2009-September 2011, 51 GTF courses were administered to 37 pediatric febrile neutropenia patients ( 25 males, 12 females; median age 89 months) with severe infections or sepsis. The clinical characteristics of the children are summarized in Table 1. Most of the children had acute leukemia (20 ALL and 15 AML). Sixteen patients had solid tumors. 
International Journal of Hematology and Oncology

Table 2. Diagnosis of infection episode

\begin{tabular}{|ll|}
\hline & Number (\%) \\
\hline Fever of unknown origin (FUO) & $11(21)$ \\
Microbiologically documented infection (MDI) & $23(44)$ \\
Clinically diagnosed infection (CDI) & $18(35)$ \\
Pneumonia & 22 \\
Upper respiratory tract infection & 8 \\
Gastroenteritis & 13 \\
Catheter infection & 2 \\
Preseptal cellulitis & 1 \\
Genital abcess & 1 \\
Conjunctivitis & 1 \\
Sepsis & 8 \\
Septic shock & 2 \\
Rhinomaxillary mucormycosis & 5 \\
\hline
\end{tabular}

In $23.5 \%$ of the episodes patients were not in remission. Three patients with leukemia received allogeneic stem cell transplantation from their HLA identical sibling. Twenty-two patients had ANC less than $100 / \mathrm{mm}^{3}$, and 29 had ANC higher than 100/mm3. In 16 of the episodes patients had central venous catheter. In 31 episodes children received G-CSF and in 15 episodes IVIG was administered in addition to antimicrobial and GTF treatment. Mucositis was present in 29 episodes and Steven-Johnson syndrome was diagnosed in 3 patients.

\section{Infections}

Microbiologically documented infections occurred in 22 episodes. Fungal infections were suspected in 9 episodes. Rhinomaxillary mucormycosis was diagnosed by biopsy during 5 episodes in 3 patients. The causative organism could not be isolated in 11 episodes. In two episodes, Gram positive cocci and in twenty-two episodes gram negative bacilli were isolated from the blood. Multiple microorganisms were identified in 5 episodes. Four patients had vancomycin resistant enterococci in their stool (Tables 2 and $3)$.

\begin{tabular}{|c|c|c|}
\hline Cultures & Pathogens & Number \\
\hline \multirow[t]{9}{*}{ Blood } & Staphylococcus epidermidis & 1 \\
\hline & Escherichia coli & 5 \\
\hline & Klebsiella oxytoca & 1 \\
\hline & Pseudomonas aeroginosa & 3 \\
\hline & Klebsiella pneumonia & 6 \\
\hline & Staphylococcus aureus & 1 \\
\hline & Stenotrophomonas maltophilia & 1 \\
\hline & Citrobacter sedlaki & 1 \\
\hline & Klebsiella pneumonia (ESBL +) & 1 \\
\hline Stool & Enterococcus (vancomycin resistant) & 4 \\
\hline Nasal biopsy & Mucormycosis & 3 \\
\hline Total & & 27 \\
\hline
\end{tabular}




\begin{tabular}{|c|c|}
\hline \multicolumn{2}{|l|}{ Recipient } \\
\hline WBC count pre-GTF & $0.4 \times 10^{3} / \mathrm{mm}^{3}\left(\mathrm{n}=46\right.$,range $\left.0.1-4.2 \times 10^{3} / \mathrm{mm}^{3}\right)$ \\
\hline WBC count $2 \mathrm{~h}$ post-GTF & $2 \times 10^{3} / \mathrm{mm}^{3}\left(\mathrm{n}=44\right.$, range $\left.0.1-37 \times 10^{3} / \mathrm{mm}^{3}\right)$ \\
\hline WBC count $24 \mathrm{~h}$ post-GTF & $1.8 \times 10^{3} / \mathrm{mm}^{3}\left(\mathrm{n}=46\right.$, range $\left.0.1-22.3 \times 10^{3} / \mathrm{mm}^{3}\right)$ \\
\hline ANC pre-GTF & $0.2 \times 10^{3} / \mathrm{mm}^{3}\left(\mathrm{n}=51\right.$,range $\left.0-0.45 \times 10^{3} / \mathrm{mm}^{3}\right)$ \\
\hline ANC post-GTF & $2.04 \times 10^{3} / \mathrm{mm}^{3}\left(\mathrm{n}=33\right.$,range $\left.0.1-16.7 \times 10^{3} / \mathrm{mm}^{3}\right)$ \\
\hline \multicolumn{2}{|l|}{ Product } \\
\hline WBC count & $158.6 \pm 66.4 \times 10^{3} / \mathrm{mm}^{3}$ \\
\hline Granulocyte count & $134.5 \pm 62 \times 10^{3} / \mathrm{mm}^{3}$ \\
\hline Granulocyte yield* & $3.1 \pm 1.2 \times 10^{10} /$ unit \\
\hline
\end{tabular}

\section{Leukapheresis and granulocyte transfusion}

All donors were male. As a mobilization protocol 43 donors received G-CSF plus dexamethasone and 8 donors received only G-CSF. Adverse reactions, mainly mild hypotension, were observed in 10 sessions. None of the procedures was terminated due to severe adverse effects. In 47 (\%92.2) of the courses, the donor blood group was $\mathrm{ABO}$ and $\mathrm{Rh}$ matched to the recipient. Donors were family members in 37 (\%72.5) of the courses. In 3 cases donors were HLA match. A total number of 51 GTFs were administered to 37 children. In 43 episodes patients received GTF once, in 7 episodes twice and in one episode GTF was administered four times. GTFs were well tolerated except one patient who had fever during transfusion. While donor's median WBC count at leukapheresis was $32.91 \times 10^{9} / \mathrm{L}$, the mean $\mathrm{WBC}$ and granulocyte counts of the products were $158.6 \pm 66.4 \times 10^{3} / \mathrm{mm}^{3}$ and $134.5 \pm 62 \times 10^{3} / \mathrm{mm}^{3}$ respectively. The mean granulocyte dose transfused to the patients was $3.1 \pm 1.2 \times 10^{10}$ cells. (Table 4).

\section{Hematological and clinical data}

The mean duration of hospitalization was $22.8 \pm 16.3$ days (solid tumors 21.3 days, leukemias 28.2 days, $\mathrm{p}=0.10$ ). The mean duration of febrile neutropenia $18.5 \pm 17.5$ days (solid tumors: 24.5 days, leukemias: 26.6 days, $p=0.64)$. There was a positive correlation between duration of hospitalization and febrile neutropenia $(p=0.00001, r=0.745)$. Granulocyte count of the product was negatively correlated with febrile neutropenia duration $(p=0.043, r=-0.284)$. The median recipient $\mathrm{WBC}$ count before, $2 \mathrm{~h}$ and $24 \mathrm{~h}$ after transfusion were $0.4 \times 10^{3} / \mathrm{mm}^{3}(\mathrm{n}=46$, range 0.1 $\left.4.2 \times 10^{3} / \mathrm{mm}^{3}\right), 2 \times 10^{3} / \mathrm{mm}^{3}\left(\mathrm{n}=44\right.$, range $0.1-37 \times 10^{3} /$ $\left.\mathrm{mm}^{3}\right), 1.8 \times 10^{3} / \mathrm{mm}^{3}\left(\mathrm{n}=46\right.$, range $0.1-22.3 \times 10^{3} /$ $\mathrm{mm}^{3}$ ) respectively. The median ANC count of the recipient before GTF was $0.2 \times 10^{3} / \mathrm{mm}^{3}(\mathrm{n}=51$, range $\left.0-0.45 \times 10^{3} / \mathrm{mm}^{3}\right)$ and median ANC of the recipient post transfusion was $2.04 \times 10^{3} / \mathrm{mm}^{3}(\mathrm{n}=33$, range $0.1-16.7 \times 10^{3} / \mathrm{mm}^{3}$ ) (Table 4). Thirty-nine (76.5\%) of the neutropenic febrile episode resolved from infection and discharged from the hospital. In 12 episodes $(23.5 \%)$ the patients died in, seven of them were refractory to treatment, two of them were at the initial stages of treatment and three of them had relapsed disease. There was no statistically significant difference in the ANC, procalcitonin, administration of G-CSF, underlying malignancy (leukemia vs solid tumor), granulocyte product or WBC content between survivors and non-survivors $(p>0.05)$. The presence of microbiologically documented infection $(p=0.044)$ and IVIG administration $(p=0.04)$ were statistically significant in non-survivors.

\section{DISCUSSION}

Overwhelming infection in neutropenic cancer patients has a high mortality despite modern anti-infective treatment regimens and achievements made in intensive care management. ${ }^{5}$ Although the neutrophil transfusion therapy has been available since 1960s, its role in the management of febrile neutropenia had been controversial. In the 1960s granulocytes obtained from chronic myeloid leukemia patients with high granulocyte counts gave hopeful results. ${ }^{6} \mathrm{Be}$ tween 1970 to 1980 the clinical trials yielded mixed 
results. An explanation for this variability could be the dose of the granulocytes transfused. ${ }^{7-11}$ Metaanalysis suggested that higher doses given resulted in better clinical efficacy. ${ }^{12-13}$ GTF disappeared from clinical use between 1980 to 1990 due to improvements in general supportive care and new antimicrobials, combined with the difficulties in collecting granulocytes. Also concerns from reports of adverse pulmonary reactions made GTF unfavorable modality of treatment. ${ }^{14}$ Interest in GTF was renewed in the 1990s after the discovery and availability of recombinant granulocyte colony stimulating factor (G-CSF). ${ }^{15-16}$ The introduction of G-CSF to stimulate healthy donors has enabled to collect sufficient amounts of granulocytes that are more functional and resistant to apoptosis. ${ }^{17-18}$ Additional improvements in leukapheresis techniques and erythrocyte sedimentation techniques have resulted in efficient collection of granulocytes. ${ }^{4,19,20}$

Price et al. have shown that transfusion of granulocytes harvested from donors stimulated with G-CSF and dexamethasone could restore neutropenia in patients and the infection has been resolved in eight of 11 patients with invasive bacterial infections and candidemia. ${ }^{21}$ Peters et al. in their prospective study of 30 pediatric patients receiving GTF demonstrated that 14 out of 17 patients with bacterial infection survived on day 100 after the first GTF. However, treatment of fungal infections was much less effective. ${ }^{22}$ Hester et al. treated 15 patients with established fungal infections and reported that $60 \%$ responded to transfusion. ${ }^{23}$ In a retrospective uncontrolled observational study of neutropenic pediatric patients with sepsis who received GTF, 19 of 32 patients survived sepsis and the survivors had a significant decrease in C-reactive protein. ${ }^{2}$ Other authors also documented that GTF is generally well tolerated and short term survival was good in pediatric oncology and HSCT patients with neutropenic sepsis. ${ }^{3,4,24}$

GTF is recommended when the absolute neutrophil count is less than 500 cells/microliter, when there is evidence of bacterial or fungal infection, unresponsiveness to aggressive antimicrobial treatment and no recovery of neutrophil count expected for more than 7 days. ${ }^{25}$ In our study, all patients were in the high risk group. In 43 of the episodes, patients received GTF once. The process of granulocyte donation can be burdensome for donors. Donors must take three trips to the donation center; first for donor screening and testing, second for medication administration and third for the leukapheresis procedure. Although in our case series donors were family members in $72.5 \%$ of the courses, the inconvenience of the process to the donor was a limiting factor to GTF given to the patients. The dose of the granulocytes administered is a key factor in response to GTF. We also found that granulocyte count of the product was negatively correlated with the duration of febrile neutropenia. The mean granulocyte yield of the apheresis concentrates was $3.1 \pm 1.2 \times 10^{10}$ (Table 4) which met the requirement of minimum recommended dose of $1 \times 10^{10}$ per transfusion. ${ }^{13,26}$ Granulocytes were well tolerated and no donor or patient related major complication was observed. The short term complete response rate was $76.5 \%$. Of the non-survivors ten had uncontrolled progression of their disease and two were at the initial stages of treatment. The duration of hospitalization and duration of febrile neutropenia was not statistically significant in patients with solid tumor vs leukemia. In eight of the non-survivors microbial infection was documented and seven of them received IVIG treatment.

Our data show that GTF is well tolerated and may be a useful therapeutic tool in high-risk neutropenic pediatric oncology patients. However, with this case series we cannot make conclusions regarding the appropriate application of GTF. Despite ethical issues with randomization in life-threatening infectious complications during neutropenia, well designed controlled study in pediatric oncology and HSCT patients are required to confirm the benefits of prophylactic and therapeutic GTF treatment. A phase III randomized controlled multicenter clinical trial (the RING study: "resolving infection in people with neutropenia") of GTF therapy has been launched by National Heart, Lung, and Blood Institute. This study will evaluate the benefit of treating patients with GTF therapy in patients with bacterial and fungal infections. ${ }^{27}$ GTF might be considered as an additional supportive care of potential use until the results of that study is published.

\section{REFERENCES}

1. Koh AY, Pizzo PA. Infectious complications in pediatric cancer patients: In Principles and Practice of Pediatric Oncology, 6th Ed, Pizzo PA, Poplack GA(eds), Lippincott, Williams \&Wilkins, 2010: 1190-1242. 
2. Grigull L, Pulver N, Goudeva L, et al. G-CSF mobilised granulocyte transfusions in 32 paediatric patients with neutropenic sepsis. Support Care Cancer 14: 910-916, 2006.

3. Cesaro S, Chinello P, De Silvestro G, et al. Granulocyte transfusions from G-CSF-stimulated donors for the treatment of severe infections in neutropenic pediatric patients with oncohematological diseases. Support Care Cancer 11: 101-106, 2003.

4. Sachs UJ, Reiter A, Walter T, et al. Safety and efficacy of therapeutic early onset granulocyte transfusions in pediatric patients with neutropenia and severe infections. Transfusion 46: 19091914, 2006.

5. Hallahan A, Shaw P, Rowell G, et al. Improved outcomes of children with malignancy admitted to a pediatric intensive care unit. Crit Care Med 28: 3718-3721, 2000.

6. Price $\mathrm{TH}$. The current prospects for neutropil transfusions for the treatment of granulocytopenic infected patients. Transfus Med Rev 14: 2-11, 2000.

7. Graw RG Jr, Herzig G, Perry S, et al. Normal granulocyte transfusion therapy: treatment of septicemia due to gram-negative bacteria. N Engl J Med 287: 367-371, 1972.

8. Alavi JB, Root RK, Djerassi I, et al. A randomized clinical trial of granulocyte transfusions for infection in acute leukemia. $\mathrm{N} \mathrm{Engl}$ J Med 296: 706-711, 1977.

9. Vogler WR, Winton EF. A controlled study of the efficacy of granulocyte transfusions in patients with neutropenia. Am J Med 63: 548-555, 1977.

10. Herzig RH, Herzig GP, Graw RG Jr, et al. Successful granulocyte transfusion therapy for gram-negative septicemia. A prospectively randomized controlled study. N Engl J Med 296: 701-705, 1977.

11. Winston DJ, Ho WG, Gale RP. Therapeutic granulocyte transfusions for documented infections. A controlled trial in ninetyfive infectious granulocytopenic episodes. Ann Intern Med 97: 509-515, 1982

12. Strauss RG. Therapeutic granulocyte transfusions. Blood 81: 1675-1678, 1993.

13. Vamvakas EC, Pineda AA. Meta-analysis of clinical studies of the efficacy of granulocyte transfusions in the treatment of bacterial sepsis. J Clin Apher 11: 1-9, 1996.

14. Wright DG, Robichaud KJ, Pizzo PA, et al. Lethal pulmonary reactions asssociated with combined use of Amphotericin $\mathrm{B}$ and leukocyte transfusion. N Eng J Med 3041: 185-189, 1981

15. Hübel K, Dale DC, Engert A, Liles WC. Current status of granulocyte (neutrophil) transfusion therapy for infectious diseases. J Infect Dis 183: 321-328, 2001.

16. Price TH, Chatta GS, Dale DC. Effect of recombinant granulocyte colony-stimulating factor on neutrophil kinetics in normal young and elderly humans. Blood 88:335-340, 1996.

17. Joos K, Herzog R, Einsele H, et al. Characterization and functional analysis of granulocyte concentrates collected from donors after repeated G-CSF stimulation. Transfusion 42: 603611, 2002.
18. Leavey PJ, Thurman G, Ambruso DR. Functional characteristics of neutrophils collected and stored after administration of G-CSF. Transfusion 40: 414-419, 2000.

19. Atallah E, Schiffer CA. Granulocyte transfusion. Curr Opin Hematol 19: 1345-1349, 2005.

20. Price TH. Granulocyte transfusion: current status. Semin Hematol 44: 15-23, 2007.

21. Price TH, Bowden RA, Boeckh M, et al. Phase I/II trial of neutrophil transfusions from donors stimulated with G-CSF and dexamethasone for treatment of patients with infections in hematopoietic stem cell transplantation. Blood 95: 3302-3309, 2000.

22. Peters C, Minkov M, Matthes-Martin S, et al. Leucocyte transfusions from rhG-CSF or prednisolone stimulated donors for treatment of severe infections in immunocompromised neutropenic patients. Br J Haematol 106: 689-696, 1999.

23. Hester JP, Dignani MC, Anaissie EJ, et al. Collection and transfusion of granulocyte concentrates from donors primed with granulocyte stimulating factor and response of myelosuppressed patients with established infection. J Clin Apheresis 10: 188-193, 1995.

24. Atay D, Ozturk G, Akcay A, et al. Effect and Safety of Granulocyte Transfusions in Pediatric Patients With Febrile Neutropenia or Defective Granulocyte Functions. J Pediatr Hemato Oncol 33: 220-225, 2011.

25. Bishton M, Chopra R. The role of granulocyte transfusions in neutropenic patient. Br J Haematol 127:501-508,2004.

26. Engelfriet CO, Reesink HW. Granulocyte transfusions. Vox Sang 79: 59-96, 2000.

27. Dale DC, Price TH. Granulocyte transfusions therapy: a new era? Curr Opin Hematol 16: 1-2, 2009.

\section{Correspondence}

Dr. Gülay SEZGIN

Çukurova Üniversitesi Tıp Fakültesi

Pediatrik Onkoloji Bilim Dalı

Kemik liıği Nakli Ünitesi

Balcalı, 01330, ADANA / TURKEY

Tel: (+90.322) 3387444

Fax: (+90.322) 3387444

e-mail: gulaysezgin@yahoo.com 